ACTA UNIVERSITATIS LODZIENSIS

FOLIA LITTERARIA POLONICA 4(34) 2016

http://dx.doi.org/10.18778/1505-9057.34.20

Teresa Kostkiewiczowa*

\title{
Kwestia interpunkcji w utworach poetyckich Ignacego Krasickiego. Spostrzeżenia i uwagi w związku z edycją krytyczną wierszy
}

Problemy ustalenia interpunkcji w edycjach krytycznych dzieł pisarzy dawnych należą do trudniejszych i bardziej skomplikowanych. Wiąże się to $\mathrm{z}$ wieloma czynnikami, które w minionym czasie decydowały o sposobach rękopiśmiennego utrwalania i drukarskiego przekazu tekstów ${ }^{1}$. Należą do nich: z jednej strony - ustalone mniej lub bardziej dokładnie przez językowych prawodawców lub utrwalone w praktyce (pisarskiej, wydawniczej) zasady przestankowania, związane $\mathrm{z}$ etapem rozwojowym języka $\mathrm{w}$ danym momencie historycznym, $\mathrm{z}$ drugiej zaś - indywidualne nawyki autora lub drukarza, ukształtowane w trakcie nauki szkolnej lub płynące ze świadomego projektowania odbioru tekstu poprzez zastosowanie określonych znaków interpunkcyjnych. W przypadku dzieł Ignacego Krasickiego sprawę dodatkowo komplikują jego obyczaje pisarskie. Obserwacja zachowanych rękopisów XBW pozwala stwierdzić, że rzadko stosował on konwencjonalne znaki interpunkcyjne, a w szczególności przecinki, pomijał też znaki interpunkcyjne $\mathrm{w}$ - traktowanej jako sygnał przedziału intonacyjnego - klauzuli wersów. Często posługiwał się też oznaczeniami własnymi, takimi jak: pozioma kreska zamiast kropki na końcu zdania, myślniki w miejscach, gdzie dziś stawia się średnik lub kropkę, kreska pionowa i dwukropki zamiast nawiasów, a na przykład w satyrach, gdzie występuje dialog bohaterów, nie używał cudzysłowów, a jedynie myślniki, których nagromadzenie zamąca jasność przynależności kwestii do kolejnych postaci².

Pierwodruki i - generalnie - publikacje osiemnastowieczne ukazują przede wszystkim nawyki drukarzy, którzy nie zawsze trafnie odczytywali sens tekstu,

${ }^{*}$ Prof. zw. dr hab., Instytut Badań Literackich Polskiej Akademii Nauk, ul. Nowy Świat 72, 00-330 Warszawa; e-mail: terkost@o2.pl

${ }^{1} \mathrm{Na}$ ten temat zob. T. Chachulski, O interpunkcji Franciszka Dionizego Kniaźnina, w: Wobec romantyzmu. Studia i szkice ofiarowane Profesor Danucie Zamacińskiej-Paluchowskiej, red. M. Łukaszuk i M. Maciejewski, Lublin 2006, s. 61-62.

${ }^{2}$ Pełną charakterystykę interpunkcji w rękopisach Krasickiego daje Z. Goliński we Wstępie do: I. Krasicki, Dzieła zebrane, t. 1: Poematy, oprac. Z. Goliński, Zakład Narodowy im. Ossolińskich, Wrocław 1998, s. 70-74. 
na przykład bezrefleksyjnie oddzielając przecinkiem grupę podmiotu od grupy orzeczenia w różnego typu zdaniach. Wprowadzenie ładu interpunkcyjnego było dodatkowo utrudnione na skutek stosowania przez Krasickiego licznych inwersji, a czasem - skomplikowanego szyku przestawnego.

W zbiorowej edycji Franciszka Ksawerego Dmochowskiego wydawca starał się uporządkować przestankowanie i wprowadzał własne rozwiązania, wyraźnie nadużywając przy tym niektórych znaków, na przykład dwukropków, stosowanych w różnych sytuacjach tekstowych i w wielu funkcjach; oszczędnie gospodarując przecinkami, które często zastępował średnikiem, dlatego też jego rozwiązania nie mogą być w tym przypadku miarodajne. Przygotowanie krytycznej edycji dzieł Krasickiego wymaga zatem również w tym zakresie szczególnej uwagi i podejmowania decyzji co do interpunkcji w oparciu - przede wszystkim - o analizę sensu tekstu oraz dzisiejsze normy w tym zakresie.

Badacze twórczości XBW już parokrotnie zwracali uwagę na niezbędność weryfikacji niektórych przyjętych w dotychczasowych edycjach rozwiązań, formułując propozycje przekonujące trafnością rozumienia poddawanych analizie zdań. Juliusz Kleiner zauważył na przykład potrzebę zmiany interpunkcji przyjętej i zwyczajowo stosowanej w różnych edycjach w Żonie modnej (S I 8)3. W wyniku analizy sensu wersów 6-7 utworu doszedł on do wniosku, że - wbrew rozstrzygnięciu wprowadzonemu w krytycznej edycji Satyr Ludwika Bernackiego (SLB) - w wersie 6 zamiast zamknięcia średnikiem wypowiedzenia „Nie ze wszystkim;" powinien znaleźć się tam przecinek, ponieważ następne słowa „luboć zazwyczaj tak bywa," są kontynuacją poprzedniego wypowiedzenia, a fragment powinien mieć postać:

Nie ze wszystkim, luboć to zazwyczaj tak bywa,

Pierwsze czasy cukrowe 5 .

Koniektura ta wydaje się przekonująca i powinna być wprowadzona do nowej edycji krytycznej satyr, tym bardziej, że przecinek w tymże miejscu znajduje się w autografie brudnopisowym Satyr ${ }^{6}$. Podobne rozumowanie - choć dotyczące nieco innej kwestii interpunkcyjnej - przeprowadził Józef Tomasz Pokrzywniak w stosunku do satyry Pochwata wieku (S II 2). Dotyczy ono przypisania kwestii „To dowód oczywisty.” (w. 2), która, jak dowiódł badacz, należy do rozmówcy,

${ }^{3}$ Punktem wyjścia rozważań są teksty utworów Krasickiego zawarte w edycji Dzieła wybrane, oprac. Z. Goliński, t. 1-2, Państwowy Instytut Wydawniczy, Warszawa 1989 (dalej: EG) oraz dla Satyr-edycja L. Bernackiego: I. Krasicki, Satyry i Listy, wydanie krytyczne L. Bernackiego, Towarzystwa dla Popierania Nauki Polskiej, Lwów 1908 (dalej: SLB); zbiory poetyckie oznaczane pierwszymi literami tytułów z podaniem części zbioru - rzymską, a miejsca w zbiorze - cyfrą arabską.

${ }^{4}$ I. Krasicki, Satyry i Listy, s. 97.

${ }^{5}$ J. Kleiner, Drobiazgi z zakresu poezji stanistawowskiej. 2. Średnik czy przecinek $w$,Żonie modnej”, „Pamiętnik Literacki” 1955, z. 2, s. 501-502.

${ }^{6}$ Rkps Bibl. Ossol., sygn. 439 III (dalej: RS), Satyry, cz. I, k. 3. 
a nie do narratora satyry. Podobnie dalej - wywód zawarty w wersach 61-64 przypisać należy narratorowi, a nie jego interlokutorowi, poprzez stosowne umieszczenie cudzysłowów?

W trakcie przygotowywania edycji krytycznej dzieł Krasickiego natrafiamy na liczne inne miejsca w Satyrach, Listach, Wierszach różnych, które nasuwają wątpliwości wobec dotychczasowych rozstrzygnięć interpunkcyjnych i wymagają wnikliwej analizy, często prowadzącej do decyzji odmiennych niż we wcześniejszych wydaniach, albo też - stawiają wydawcę w sytuacji niepewności, dopuszczającej dwie odmienne interpretacje sensu tekstu. Na podstawie kilku przykładów spróbujemy zilustrować tę trudną kwestię edytorską. Przyjrzyjmy się najpierw sytuacjom mniej skomplikowanym i dość jednoznacznym.

W Świecie zepsutym (S I 1) w kadencji wersu 2 w edycji krytycznej Bernackiego (SLB) znajduje się dwukropek, zaś w Dziełach wybranych (EG) - średnik. Wydaje się jednak, że wers 4 jest częścią rozbudowanego okresu retorycznego i stanowi następnik retoryczny zawartości wersów 1-3, będąc ich bezpośrednią kontynuacją, a więc powinien być oddzielony od poprzedniej części wypowiedzi jedynie przecinkiem:

Wolno szaleć młodzieży, wolno starym zwodzić,

Wolno się na czas żenić, wolno i rozwodzić,

Godzi się kraść ojczyznę, łatwą i powolną,

A mnie sarkać na takie bezprawia nie wolno?

(w. 1-4)

W satyrze Marnotrawstwo (S I 4) znajduje się opis zmian wprowadzanych przez nowego gospodarza w starym domostwie (w. 62-66): wyrzucono z sali portrety przodków, przebudowano ją, robiąc , ,ztery z niej gabinety i dwa buduary”. I tu zaczyna się problem interpretacyjny: kolejny wers (65) zaczyna się spójnikiem „że”, został więc potraktowany przez wydawców SLB i EG jako kontynuacja zdania zawartego w wersach poprzednich. Tymczasem analiza sensu prowadzi do wniosku, że słowa „Że w nich były Starego dzieje Testamentu” są początkiem nowego zdania, rozpoczętego - jak często w wierszach Krasickiego - inwersją, sytuującą zdanie podrzędne przed nadrzędnym, notabene analogicznie, jak w części poprzedzającej: „że zbyt wielka, ścieśniają...”. Dlatego też na końcu wersu 64 powinna być kropka, a zapis z następującym przestankowaniem wydaje się jedynym możliwym:

Liczne przodków portrety wyrzucono z sali,

Natychmiast, że zbyt wielka, ścieśniają gmach stary:

${ }^{7}$ J. T. Pokrzywniak, Dylematy satyryka i moralisty: Pochwała wieku, w: Czytanie Krasickiego, pod red. T. Kostkiewiczowej, R. Doktóra, B. Mazurkowej, Wydawnictwo Instytutu Badań Literackich PAN, Warszawa 2014, s. 19-21. 
Cztery z niej gabinety i dwa buduary.

Że w nich były Starego dzieje Testamentu,

Nie cierpiano szpalerów jednego momentu:

(w. 62-66)

W satyrze Pan niewart stugi (S I 10) ukarany plagami Marcin „Płacze w kącie, więc krnąbrny, po plagach się schował,' (w. 45) i tak właśnie - z uwzględnieniem delikatnej eliptyczności zdania - powinien być zapisany: z przecinkiem po „krnąbrny”, zgodnie z lekcją: Marcin ,płacze w kącie”, więc jest krnąbrny, bo schował się po plagach. Tak jest w SLB, zaś w EG - bez przecinka po „krnąbrny”, co zamąca sens wypowiedzi.

Inne nieco problemy nastręcza satyra Gracz (S I 11). Wers 85 w EG kończy się przecinkiem po słowie „oratory”. Tymczasem sens wypowiedzi dyktuje przesunięcie tego znaku w miejsce po słowie „Naówczas”, otwierającym wers następny, ponieważ i tu spotykamy delikatną przestawnię nieco zaburzającą szyk zdania, a także - ciekawe u XBW - przerzutnie międzywersowe:

Za nic Rzymu i Aten sławne oratory

Naówczas, kiedy szuler płaczliwe perory

Rozpoczyna wybornym sposobem i kształtem:

(w. 85-87)

Należy więc wrócić do wersji przyjętej w SLB.

Drobnej korekty interpunkcyjnej w stosunku do wersji EG i powrotu do SLB wymaga wers 14 satyry Pochwała glupstwa (S II 3). Mamy tam szereg wyliczeniowy tego, co zrobił Paweł, więc nie ma potrzeby przedzielania go kropką, która rozrywa ciągłość wypowiedzi; wystarczy w prowadzenie przecinka:

Skoro wszedł, wszystkich zgłuszył, Michała przegadał,

Michała, co wiek z księgą trawi w gabinecie.

(w. 14-15)

W satyrze Człowiek i zwierz (S II 5) dla podjęcia decyzji co do przestankowania potrzebna jest analiza treści dłuższego fragmentu tekstu. Prowadzi ona do wniosku, że - tak jak w SLB - w klauzuli wersu 101 powinien być przecinek, a nie kropka (jak w EG), ponieważ wers ten stanowi rozwinięcie (dopowiedzenie) zawartości myślowej poprzedniego:

Nie na tym się zasadza człecza doskonałość,

Towarzystwo cel jego, do niego stworzony,

Rodzice, dzieci, bracia, i męże, i żony.

(w. 100-103) 
Podobne kwestie pojawiają się również w innych zbiorach poetyckich Krasickiego. W wierszu Czerwony złoty (WR 8) wers 14 w EG zamknięty jest kropką, podczas gdy daje się on czytać jako „z ołtarza spadłem,” (z przecinkiem w klauzuli), ponieważ występuje tam elipsa zwrotu ,a więc”, który wskazuje bezpośredni związek wynikania z drugim członem wypowiedzenia:

Przyszło do tego, że z ołtarza spadłem, Trzeba pójść było na nowe obroty:

(w. 14-15)

Niekiedy musimy podjąć decyzję w sytuacjach nie całkiem wyrazistych, jak na przykład w wierszu Laur (WR 10), gdzie na granicy wersów 4 i 5 wydaje się bardziej zasadny średnik, a nie przecinek, ponieważ w następnym wersie następuje wypowiedzenie wprowadzające nowy motyw treściowy:

Szczepu dobrego ulubiony płodzie,

$[\ldots]$

Na coraz nowe wdzięki się zdobywasz;

Laurze, ja, wieśniak spokojny w umyśle,

Pod twoim cieniem, pozwól, niechaj myślę.

(w. 1,4-6)

Rodzaj znaku przestankowego na końcu wersu 4 nie wpływa tu wprawdzie na sens wypowiedzi, która w obu wypadkach zachowuje tę samą intencję znaczeniową, ale wyraziściej określa relacje składniowe między jej składnikami. Podobnie w wierszu [inc. „Panie Antoni, jużeśmy starzy...”] (WR 11), granica składniowa między wersami 11 i 12 wydaje się bardziej wyrazista niż wskazywałby na to przecinek, dlatego uzasadniona wydaje się tam kropka:

Boim się wzajem, źle koło ojczyzny,

Na pogotowiu zabójstwa, trucizny,

Aż twoja złota korona zbyt cięży,

Mnie mija mitra gnębi i ciemięży.

Kto inszy w Gnieźnie, kto inszy na tronie,

$[\ldots]$

(w. 8-12)

Ale już w utworze [inc. „Mości książę Poniatowski...”] (WR 20) decyzja co do umieszczenia przecinka zmienia rozumienie relacji między składnikami wypowiedzi, a także jej znaczenie. Problem dotyczy przestankowania w wersie 3, który w EG zapisany jest w postaci: 
Opisanie twojej wioski

Daje znać pomyślnym stanem,

Że umiesz być dobrym panem.

(w. 2-3)

Tymczasem relacje te można interpretować inaczej, w sensie: „Opisanie ... pokazuje, że w pomyślnym stanie umiesz być dobrym panem”, co wydaje się bardziej zasadne w sytuacji, kiedy utwór mówi o „ludzkości” właściciela uwłaszczającego poddanych w swych dobrach.

Podobnie w Pamiatce Andrzejowi Mokronowskiemu wojewodzie mazowieckiemu (WR 30) usytuowanie przecinków w wersie 6 wyznacza rozumienie tekstu. W wersji „Zgasłeś, mężu szacowny, przez świętą szczodrotę.” (tak w EG) pojawia się niejasność, dlaczego ,szczodrość” miałaby być przyczyną zgonu. Właściwa wydaje się zatem lekcja: „Zgasłeś mężu, szacowny przez swoją szczodrotę.", kiedy druga część wersu rozumiana jest jako kolejny element pośmiertnej pochwały bohatera. Podobnie w dalszym toku wywodu zaproponowano zmianę przestankowania, wprowadzając w wersie 21 przecinek po słowie ,skromny", a usuwając go na granicy wersów 21 i 22, co pozwala uwydatnić w postępowaniu bohatera walor połączenia hojności i skromności oraz wewnętrznego, niemanifestowanego (,pod wdzięku swobodą”) poczucia satysfakcji z bycia poczciwym:

Hojny dawca, a skromny, pod wdzięku swobodą

Czułeś, jaka podściwość jest sobie nadgrodą.

(w. 21-22)

Ciekawym przypadkiem jest kwestia interpunkcji na granicy wersów 18 i 19, a zarazem granicy strofy czwartej i piątej utworu Dworak (WR 34). Strofa czwarta zawiera rozległe wypowiedzenie przedstawiające zachowanie rolnika, który:

Wraca zziajan ku stodole,

Kędy krówki wytuczone,

Krówki, co wygodnie mieścił,

Co chował, karmił i pieścił,

Puszcza w wolność.

(w. 15-19)

Umieszczenie kropki w klauzuli wersu 18 (tak w EG) zniekształca sens całości, w której słowa wersu 19 są częścią rozbudowanego zdania podrzędnie złożonego, opowiadającego o wypuszczeniu (na wiosenną łąkę) zamkniętego dotąd bydła. 
Istotną zmianę sensu powoduje też odmiana przestankowania w ostatnich wersach wiersza Do pana Ignacego (WR 50):

\author{
Słodko, mile \\ Ten używa, \\ Który bywa \\ Zawżdy czujny, \\ Bo zysk bujny \\ Tam, gdzie praca, \\ Ubogaca.
}

(w. 24-30)

Lekcja: „Bo zysk bujny / Tam, gdzie praca, / Ubogaca.” (tak w EG) jest także możliwa (w sensie: Bujny zysk ubogaca tam, gdzie się pracuje), wydaje się jednak, że zapis przedstawiony wyżej jest bliższy intencji całego wywodu o niezbędności wysiłku dla osiągnięcia życiowych korzyści („Któż bez pracy / Zyskał szczęście / I zamęście? w. 1-3).

Przez ten przykład zbliżamy się do przypadków najbardziej skomplikowanych, w których możliwe i dopuszczalne jest dwojakie usytuowanie znaków interpunkcyjnych i - co za tym idzie - dwojaka interpretacja sensu wypowiedzenia. Sporo takich miejsc znajdujemy w Satyrach. W Ztości ukrytej i jawnej (S I 2) występuje opowieść o filutach, którzy sprytnym oszustwem zdobyli pańskie majątki, a teraz pożyczają „,łużnikom oświeconym” (w. 96). To ci wyzbyci z majątków i zadłużający się panowie:

Dumą wewnątrz nadęci, zbytkiem poupadli,

Nie wstydzą się ci żebrać, u tych, co je skradli;

Oszukani klną na dal, a łaszą się z bliska,

Śmieje się pan Mikołaj, a majętność zyska.

(w. 97-100)

Wątpliwość i wahanie towarzyszą odczytaniu wersu 99. Czy winniśmy czytać: Oszukani, klną na dal, a łaszą się z bliska,” (tak w EG), czy: „Oszukani klną na dal, ..." (tak w SLB)? W lekcji pierwszej nacisk pada na fakt oszukania do niedawna majętnych panów, w drugiej - na to, że z dala od nowego właściciela ich dóbr zachowują się oni wobec niego nieprzyjaźnie, ale są pokorni przed jego obliczem. Obie wersje nie są sprzeczne z treścią całego wywodu, obie dopuszczalne i sensowne. Którą ma więc wybrać edytor? Autograf RS nie może tu być rozstrzygający, bo choć po słowie „oszukani” nie ma tam przecinka, a jest po „na dal", ale nie ma go też na końcu wersu, gdzie jest oczywiście niezbędny, autor nie był więc - jak zazwyczaj - konsekwentny w stosowaniu znaków przestankowych. 
Edytor skazany jest na decyzję arbitralną, może skłonić się ku takiej, która wydaje mu się zręczniejsza, ale w komentarzu winien zasygnalizować tę skomplikowaną sytuację tekstową.

W satyrze Szczęśliwość filutów (S I 3) podobne trudności nastręcza wers 96. W edycjach EG i SLB brzmi on: „Trzódko mała wśród łotrów, niewiele zyskacie,". W RS i w pierwodruku z 1779 roku w wersie tym nie ma żadnych znaków przestankowych, tak więc umieszczenie ich w edycjach było arbitralną decyzją wydawców. Ale kontekst tego wersu dopuszcza, a nawet sugeruje inną jego lekturę:

Modnej maksym nauki że się nie trzymacie,

Trzódko mała, wśród łotrów niewiele zyskacie.

(w. 95-96)

Wydaje się bowiem, że spotykamy tu częstą w wierszach XBW sytuację szyku przestawnego, którą rozwinąć można następująco: „Trzódko mała [znajdująca się wśród łotrów] ponieważ nie trzymacie się nauki modnych maksym [tychże łotrów], niewiele wśród nich zyskacie”. W takim ujęciu zwrot „trzódko mała” logicznie poprzedza zawartość wersu 95, a w zastosowanym przez poetę układzie powinien być wyodrębniony przecinkami, natomiast zwrot „wśród łotrów” jest okolicznikiem dopełniającym orzeczenie ,zyskacie”. Lekcja taka jest przekonująca jako alternatywa poprzednio przyjętej, co nie wyklucza możliwości czytania zapisanego wcześniej.

Podobnie - zapisy alternatywne dopuszczalne są w wersach 26-27 satyry Pijaństwo (S I 6):

Więc ja znowu do wódki, wypiłem niechcący:

Omne trinum perfectum, choć trunek gorący,

Dobry jest na żołądek.

(w. 25-27)

Niejasność dotyczy relacji między wyrażeniami „trunek gorący” i „dobry jest na żołądek.": czy trunek ten jest dobry, mimo że gorący, czy też - dlatego, że jest gorący. W EG i SLB przyjęta jest lekcja druga (bez przecinka po „gorący”), tymczasem wydaje się, że bardziej zasadne jest brzmienie w wersji z przecinkiem, ponieważ spójnik „choć” sugeruje przeciwstawienie (gorący, ale mimo to dobry). Rozstrzygnięcie tej kwestii jest jednak - jak w poprzednich przypadkach - kwestią przekonania i decyzji edytora.

Szczególnie dużo tego typu niejednoznacznych sytuacji tekstowych znajduje się w ważnej w zbiorze i mającej niebanalną konstrukcję satyrze Palinodia (S I 12). Oto wybrany przykład: 
Każdego w szczególności, wszystkich chwalę wspołem.

Jak Piotr, Paweł, z osobna, mnogimi orszaki

Przystępujcie szulery, oszusty, pijaki,

(w. 62-64)

Kontrowersja dotyczy przecinka po słowie „Paweł”: czy to on przystępuje „z osobna” (tak - bez przecinka - w EG i SLB), czy też ,z osobna” to oddzielna kategoria przystępujących, przeciwstawna wobec przystępujących ,mnogimi orszaki", a więc oddzielona przecinkiem. Wydaje się, że chodzi tu raczej o przeciwstawienie: tych, którzy mają podchodzić pojedynczo i tych w „mnogich orszakach”, dlatego potrzebny jest ten przecinek po „Paweł”, ale odmienna lektura jest też dopuszczalna. Podjęcie decyzji co do zapisu tekstu zależy od decyzji edytora.

Część druga Satyr nie uwalnia od zmierzenia się z podobnymi sytuacjami. W satyrze Wziętość (S II 4) trudność sprawia lekcja wersów 55-54, które trzeba przytoczyć w szerszym kontekście, pozwalającym lepiej zrozumieć ich sens:

Nie czuł nasz pan Mikołaj i chociaż przewinił,

Grzech mały według niego, on ledwo nie świętym.

Nowy przeto teolog kunsztem niepojętym,

Bezpłatny kraju sędzia, przestawając na tym,

Sądził, karał, doradzał i stał się bogatym.

(w. 52-56)

Problem dotyczy potrzeby wprowadzenia przecinka po „teolog”: od niego zależy, czy zwrot „,kunsztem niepojętym” odnosi się do teologa i sposobu zdobycia przezeń kwalifikacji do sądowniczego orzekania - jak chcielibyśmy to czytać, czy też - do tego właśnie orzekania przy użyciu ,niepojętego kunsztu (jak w EG i SLB). Jak wybrnąć z tego zawiłego dylematu? Takie czy inne jego rozwiązanie nie rzutuje wprawdzie na sens całego utworu, jest kwestią rozumienia tego tylko fragmentu, wymaga jednak edytorskich decyzji rzutujących na ostateczny kształt tekstu.

Również w zbiorze listów poetyckich natrafiamy na miejsca niejednoznaczne i wymagające edytorskiej refleksji. Oto przykład z êpitre'u Do ks. Adama Naruszewicza koadiutora smoleńskiego (L 6):

Nie stąd ją [prawdę] Aleksandra przemożność porusza,

Iż z garstką mężnych przemógł Daryjusza,

Lecz gdy młody wstrzymał się, płakał nad zgnębionym.

(w. 97-99)

Dylemat dotyczy tego, czy przymiotnik „,młody” należy czytać jako proste zwrócenie uwagi na wiek wojownika (wtedy słowo umieszczone bez przecinków), 
czy też eliptycznie - mimo iż był młody (a więc - w domyśle - niemający jeszcze doświadczenia, wiedzy o życiu, a zarazem niecierpliwy, szybki), umiał okazać współczucie starszemu pokonanemu; wtedy - między przecinkami. Która z lekcji jest bardziej uzasadniona i przekonująca? To należy do decyzji edytora.

Wśród wierszy różnych przykładu ambiwalencji interpunkcyjnych dostarcza między innymi utwór [inc. „Żenisz się. I przykładna matka, dobra żona...”] (WR 62). W drugiej jego strofie czytamy:

Bóg takie słodkie węzły przy cnocie kojarzy.

Żeś szedł drogą nie młodych, lecz drogą, co starzy,

Zyskasz, i co istota, i co jest przydatek:

Stan szczęśliwy, spokojność, słodycz i dostatek.

(w. 5-8)

Taką lekcję, wyznaczoną zastosowanymi znakami interpunkcyjnymi, proponuje przygotowywana edycja wierszy. Ale w EG występuje inny rozkład tych znaków $\mathrm{i}$ - w związku z tym - odmienne rozumienie tekstu strofy:

Bóg takie słodkie węzły przy cnocie kojarzy,

Żeś szedł drogą nie młodych, lecz drogą, co starzy.

Zyskasz i co istota, i to, co przydatek:

Stan szczęśliwy, spokojność, słodycz i dostatek.

W tym drugim przypadku Bóg spowodował zawarcie „słodkich węzłów” jako swoistą nagrodę za wybranie drogi wyznaczonej przez starych, co jest oczywiście zgodne z waloryzacją przez Krasickiego dawności oraz z całościową ideą tej wypowiedzi poetyckiej. Przy rozwiązaniu pierwszym - nagrodą za wybór tej drogi jest jeszcze coś więcej: zyskanie tego, co jest istotą („słodkie więzy”, „spokojność, słodycz") i tego, co jest w perspektywie uniwersalnej przydanym do nich dodatkiem okazjonalnej Fortuny: „dostatek”. Obie wersje lektury wydają się uprawnione, ale edytor musi tu podjąć jednoznaczną decyzję co do postaci tekstu.

Oddzielnym problemem edytorskim jest lektura satyr dialogowych, w których głos zabierają dwie postacie: narrator i jego interlokutor. Sprawa decyzji co do przypisania określonych kwestii poszczególnym rozmówcom została przedstawiona w przywołanym na początku artykule J.T. Pokrzywniaka. Okazuje się jednak, że dotyczy ona również kilku innych utworów, które wymagają uważnej, wnikliwej analizy toku wypowiedzi i podjęcia decyzji co do repartycji jej części, a taka zaś ingerencja może mieć duże znaczenie dla rozumienia sensu całego utworu. Nie odnosząc się do tej kwestii całościowo, zilustrujmy ją przykładem satyry Życie dworskie (S I 9). Początek utworu to zwrot i skierowana do Joachima (przedstawionego dalej jako ktoś, kto spędził życie „między dworską zgrająa” 
i jest określony jako dworak) prośba postaci mówiącej (narratora, który siebie nazywa „wieśniakiem”) o informację „Na czym zawisło, jakie u dworu jest życie?” (w. 8). W sytuacji, kiedy indagowany nie odpowiada („Milczysz?” w. 9), narrator deklaruje, że sam przedstawi dworską rzeczywistość i jej bohaterów. Następuje ośmiowersowy monolog (w. 10-17), zakończony kolejny pytaniem:

Panie Joachimie,

Powiedz, co tam [na dworze] w ohydzie, a co tam w estymie?

(w. 17-18)

W kolejnym wersie pojawia się jednowyrazowe wypowiedzenie: „Cnota.” (w. 19). W EG wyraz ten nie jest umieszczony w cudzysłowie, a więc potraktowany jako kontynuacja wypowiedzi narratora. Tyle tylko, że w dalszym jej ciągu mówi on:

Waszmość żartujesz. Kunsztem wielorakiem

Umiałeś żyć u dworu i jesteś dworakiem.

A ja prostak, a przecież chciałbym z tego toru

Coś pojąć i określić, jak żyją u dworu.

(w. 19-23)

Dalej następuje obszerne opowiadanie, przedstawiające różne obrazki z życia dworskiego i różnych jego uczestników, których słowa są także przytaczane w mowie niezależnej. Joachim, do którego skierowana jest cała wypowiedź, nie zabiera już głosu i ponownie przywołany jest dopiero w końcu utworu, w kolejnym do niego zwrocie, zawierającym przeciwstawiony dworskiemu obraz życia wiejskiego i zamkniętym apostrofą do „Wsi swobodnej”. Gdyby - zgodnie ze wskazaniem zapisu bez cudzysłowu - wypowiedzenie „Cnota” przypisać głównemu narratorowi, nie tłumaczyłyby się jego słowa „Waszmość żartujesz.”, a także nie dałoby się obronić wprowadzenia Joachima jako jedynie biernego słuchacza, niereagującego na opinie głównej postaci mówiącej. Sprawa jest jednak jeszcze bardziej zawikłana i zastanawiająca. Na pytanie, co na dworze jest wzgardzone (,w ohydzie”), a co „W estymie”, pada odpowiedź „Cnota.” można więc zadać pytanie, do którego członu poprzedniego wywodu się ono odnosi. Jeżeli jako wskazówkę potraktować kolejność wymienionych w wypowiedzi narratora członów alternatywnych, to odpowiedź ta dotyczyłaby pierwszego z nich, a więc „cnota” byłaby na dworze „W ohydzie”; jeśli nie brać tego pod uwagę - byłaby „w estymie”. Wydaje się, że niejednoznaczność lakonicznej odpowiedzi Joachima jest zamierzonym środkiem ukazania zarówno dworskiej umiejętności unikania jasnych, wyrazistych opinii, jak i obłudnej postawy dworaka, który w każdym momencie prowadzi grę z otoczeniem. 
Przedstawione przykłady problemów z ustaleniem interpunkcji w utworach poetyckich Krasickiego ilustrują nie tylko zakres trudności, jakie rozstrzygnięcia na tym poziomie tekstu stoją przed wydawcą, ale także odsłaniają szersze wymogi i obligacje, z jakimi musi się on zmierzyć. Świadczą one - jak się wydaje - również o tym, że decyzje edytorskie dotyczące podstawowego zadania edycji krytycznej: ustalenia opartej o krytykę tekstu jego postaci, nie wyczerpują się w odniesieniu do kwestii formalnej - wyboru określonego jego kształtu i brzmienia. Wymagają one bowiem wnikliwej lektury i analizy wszystkich warstw wypowiedzi poetyckiej, mozolnego docierania do jej znaczeń i uzasadnienia podejmowanych rozwiązań w drodze zabiegów, które znacznie wykraczają poza kwestie czysto tekstologiczne i dotyczą jego zawartości myślowej. Wszystko to pozwala stwierdzić, iż działania edytorskie są rodzajem interpretacji utworu, poprzedzonej namysłem nad jego organizacją językową i prowadzącej nie tylko do ustalenia jego podstawy tekstowej, ale równocześnie - nadbudowanego nad nią sensu. W tej perspektywie rola edytorstwa naukowego w obszarach nauki o literaturze rysuje się znacznie bogaciej i pełniej, jako wstępna niezbędna czynność interpretacyjna.

\section{Bibliografia}

\section{Podmiotowa}

Krasicki Ignacy, Dzieła wybrane, oprac. Z. Goliński, t. 1-2, Państwowy Instytut Wydawniczy, Warszawa 1989.

Krasicki Ignacy, Satyry i Listy, wydanie krytyczne L. Bernackiego, Towarzystwa dla Popierania Nauki Polskiej, Lwów 1908.

Rkps Bibl. Ossol., sygn. 439 III.

\section{Przedmiotowa}

Chachulski Tomasz, O interpunkcji Franciszka Dionizego Kniaźnina, w: Wobec romantyzmu. Studia i szkice ofiarowane Profesor Danucie Zamacińskiej-Paluchowskiej, red. M. Łukaszuk i M. Maciejewski, Lublin 2006, s. 19-29.

Goliński Zbigniew, Wstęp do: Ignacy Krasicki, Dzieła zebrane, t. 1: Poematy, oprac. Z. Goliński, Zakład Narodowy im. Ossolińskich, Wrocław 1998, s. 501-505.

Kleiner Juliusz, Drobiazgi z zakresu poezji stanisławowskiej. 2. Średnik czy przecinek w „Żonie modnej”, „Pamiętnik Literacki” 1955, z. 2, s. 7-95.

Pokrzywniak Józef Tomasz, Dylematy satyryka i moralisty: Pochwała wieku, w: Czytanie Krasickiego, pod red. T. Kostkiewiczowej, R. Doktóra, B. Mazurkowej, Wydawnictwo Instytutu Badań Literackich PAN, Warszawa 2014, s. 61-69. 


\section{Teresa Kostkiewiczowa}

\section{The issue of punctuation in poetical works of Ignacy Krasicki. Observations and remarks in connection with a critical edition of poems}

\section{(Summary)}

The issue of determining punctuation of former periods' compositions in preparation for a critical edition is complicated and arises problems often difficult to solve univocally.

This article treats of such situations based on Ignacy Krasicki's poems, proposes solutions justified by the analysis of the text's meanings and also points at situations where alternative versions are permissible. The reasoning arrives at a conclusion on editor's work including punctuation, as endeavors of interpretative nature that are important for the understanding of a text and of its meanings.

Keywords: punctuation; meaning; Ignacy Krasicki

Słowa kluczowe: interpunkcja; znaczenie; Ignacy Krasicki 